\title{
Aspectos gerais e controvertidos do acordo de não persecução cível
}

\author{
General and controversial aspects of the civil non-prosecution agreement \\ Aspectos generales y controvertidos del acuerdo de no enjuiciamiento civil
}

Recebido: 10/08/2021 | Revisado: 16/08/2021 | Aceito: 18/08/2021 | Publicado: 21/08/2021

\author{
Luiz Manoel Gomes Júnior \\ ORCID: https://orcid.org/0000-0002-8111-4549 \\ Universidade Paranaense, Brasil \\ E-mail: luizm@luizmconsultoria.com.br \\ Diogo de Araujo Lima \\ ORCID: https://orcid.org/0000-0001-8416-1327 \\ Universidade Paranaense, Brasil \\ E-mail: diogo_araujo_lima@hotmail.com \\ Jussara Borges Ferreira \\ ORCID: https://orcid.org/0000-0002-4919-6935 \\ Universidade Paranaense, Brasil \\ E-mail: jussara@bflaw.adv.br
}

\begin{abstract}
Resumo
O modelo consensual de solução de conflitos tem ganhado espaço de destaque no Direito Sancionador, seja em sua vertente penal, seja administrativa. A recente alteração do Art. $17, \S^{\circ}$ da Lei ${ }^{\circ} 8.429 / 1992$, que passou a admitir o acordo de não persecução cível, alinha-se com uma tendência nacional e internacional de superação do dogma da impossibilidade jurídica de acordos em conflitos envolvendo a Administração Pública. A inovação veicula relevante progresso no combate à corrupção, na perspectiva de resultados mais céleres e eficientes em casos envolvendo improbidade administrativa, cuja resolução não se mostrava satisfatória pelo método exclusivo da ação de improbidade. O presente estudo tem por objetivo contribuir com a construção de balizas que permitam suprir a lacuna deixada pelo legislador quanto ao modo de operacionalização do acordo (elementos, condições, limites, etc), considerando que os dispositivos legais que disciplinavam aspectos materiais e procedimentais do acordo foram vetados pelo Presidente da República. Para tanto, será utilizado o método indutivo, a partir do exame de normas jurídicas, pesquisa bibliográfica e jurisprudencial.
\end{abstract}

Palavras-chave: Administração pública; Improbidade administrativa; Consensualidade; Acordo de não persecução.

\begin{abstract}
The consensual model of conflict resolution has gained prominence in Sanctioning Law, whether in its criminal or administrative aspects. The recent amendment to Article 17, §1 of Law No. 8.429/1992, which now admits the civil non-prosecution agreement, is in line with a national and international trend of overcoming the dogma of the legal impossibility of agreements in conflicts involving the Public administration. The innovation conveys relevant progress in the fight against corruption, in the perspective of faster and more efficient results in cases involving administrative misconduct, whose resolution was not satisfactory by the exclusive method of misconduct action. The present study aims to contribute to the construction of guidelines that allow filling the gap left by the legislator regarding the mode of operationalization of the agreement (elements, conditions, limits, etc.), considering that the legal provisions that disciplined material aspects -al and procedural aspects of the agreement were vetoed by the President of the Republic. For that, the inductive method will be used, from the examination of legal norms, bibliographical and jurisprudential research.
\end{abstract}

Keywords: Public administration; Administrative dishonesty; Consensuality; Non-prosecution agreement.

\section{Resumen}

El modelo consensual de resolución de conflictos ha ganado protagonismo en el Derecho Sancionador, ya sea en su vertiente penal o administrativa. A recente alteração do Art. $17, \S 1^{\circ}$ da Lei $n^{\circ} 8.429 / 1992$, que passou a admitir o acordo de não persecução cível, alinha-se com uma tendência nacional e internacional de superação do dogma da impossibilidade jurídica de acordos em conflitos envolvendo a Administracion PUBLICA. La innovación transmite avances relevantes en la lucha contra la corrupción, en la perspectiva de resultados más rápidos y eficientes en los casos de faltas administrativas, cuya resolución no fue satisfactoria a través del método exclusivo de acción de faltas. El presente estudio tiene como objetivo contribuir a la construcción de lineamientos que permitan llenar el vacío dejado por el legislador en cuanto al modo de operacionalización del acuerdo (elementos, condiciones, límites, etc.), considerando que las disposiciones legales que disciplinaron los aspectos materiales -al y los aspectos procesales del 
acuerdo fueron vetados por el Presidente de la República. Para ello, se utilizará el método inductivo, a partir del examen de las normas jurídicas, la investigación bibliográfica y jurisprudencial.

Palabras clave: Administración pública; Deshonestidad administrativa; Consensualidad; Acuerdo de no enjuiciamiento.

\section{Introdução}

A partir do dia 23.01.2020, entrou em vigor o Pacote Anticrime - Lei n 13.964/19 que, suprimindo a vedação do Art. $17, \S 1^{\circ}$ da Lei $n^{\circ} 8.429 / 92$, passou a admitir a consensualidade no âmbito da improbidade administrativa por meio do acordo de não persecução cível (ANPC).

A inovação segue tendência já presente em diversos diplomas normativos do Direito Penal (transação penal, suspensão condicional do processo, colaboração premiada, etc.) e do Direito Administrativo (acordo de leniência, ${ }^{1}$ possibilidade de conciliação ${ }^{2}$ e mediação ${ }^{3}$ em causas do Estado, ausência de ajuizamento de execução fiscal de pequeno valor, ${ }^{4}$ possibilidade de compromisso - extrajudicial ou judicial - para eliminar irregularidade, incerteza jurídica ou situação contenciosa na aplicação do direito público, ${ }^{5}$ entre outras hipóteses).

Apesar do mérito que a inovação significou, o avanço poderia ter sido maior, não fosse o veto ao dispositivo que disciplinava os parâmetros procedimentais e materiais do acordo.

Se ao menos não inviabilizou a implementação dos acordos de não persecução cível, a medida gerou um verdadeiro "manancial de problemas práticos" (Gajardoni, et al., 2020, p. 367), em razão da carência de regulamentação acerca do regime jurídico e do modo de operacionalização do acordo (elementos, condições, limites, etc).

O método utilizado na elaboração do trabalho foi o indutivo com a abordagem de categorias consideradas fundamentais para o desenvolvimento nas perspectivas legal e dogmática sobre o tema. O levantamento bibliográfico forneceu as bases teóricas e doutrinárias a partir de livros e textos de autores de referência, tanto nacionais como estrangeiros. A fonte primeira de pesquisa é a bibliográfica que instruiu a análise da legislação constitucional e infraconstitucional, bem como a doutrina e jurisprudência que informam os conceitos de ordem dogmática.

\section{Metodologia}

O artigo pretende a análise por meio de premissas com intuito de obter conclusões prováveis, passando por conhecimentos especiais para um conhecimento geral (Lakatos \& Marconi, 2003, p. 86) em relação ao acordo de não persecução penal.

Para tanto, analisam-se os aspectos base do acordo de não persecução expressos na norma legal e na doutrina, extraindo os aspectos controvertidos, desvelando as causas da manifestação dos fatos (Lakatos \& Marconi, 2003, p. 87).

Da relação entre esses aspectos, observar-se-á a lacuna deixada pelo legislador, apresentando, assim, balizas que permitam suprir tais lacunas.

O estudo propõe-se a participar da construção de soluções para a problemática, mediante um corte metodológico no sentido de abordar, em um primeiro momento, os contornos gerais do acordo de não persecução cível, para, em seguida, enfrentar alguns pontos controvertidos, cujo equacionamento aflige a prática forense dos operadores do direito. Nessa segunda parte, serão abordados: o momento adequado para celebração do acordo, a necessidade ou não de homologação, os casos de

\footnotetext{
${ }^{1}$ A Lei n ${ }^{\circ} 12.529$ de 30.11.2011 estabeleceu a possibilidade de celebração de acordo de leniência em relação às infrações à ordem econômica, ao passo que a Lei $n^{\circ} 12.846$ de 01.08.2013, permitiu os acordos de leniência em atos contra a Administração Pública.

${ }^{2}$ Art. 10, parágrafo único da Lei no 10.259/01 e Art. 174 do Código de Processo Civil.

${ }^{3}$ Art. $3^{\circ}$ da Lei $13.140 / 15$.

${ }^{4}$ Art. 20 da Lei 10.522/02 e arts. $7^{\circ}$ e $8^{\circ}$, ambos da Lei 12.514/11.

${ }^{5}$ Art. 26 da Lei de Introdução às Normas do Direito brasileiro - Decreto-Lei 4.657/42.
} 
solidariedade passiva, a possibilidade de previsão de cláusulas pró-futuro nessa espécie de acordos, a repercussão da absolvição criminal nos acordos de não persecução cível originados do mesmo fato e, finalmente, os limites do controle judicial sobre os termos do ajuste.

\section{A Atual Redação do art. $1^{\circ}, \S 1^{\circ}$ da Lei $n^{\circ}$ 8.429/1992: Abandono do Dogma da Impossibilidade de Transação em Casos de Improbidade Administrativa}

Pelo texto originário do Art. 17, $\S 1^{\circ}$ da Lei $8.429 / 92$ (Lei de Improbidade Administrativa - LIA), vedava-se a transação, acordo ou conciliação nas ações de improbidade administrativa.

A tradição jurídica brasileira sempre foi arraigada por intensa publicização do direito em detrimento do empoderamento do indivíduo. As fontes do Direito limitavam-se àquelas produzidas pelo Estado. Em matéria processual, essa característica se apresentava de forma ainda mais intensa, considerando que processo era o espaço onde o Estado exprimia a sua autoridade (Tavares, 2018, p. 33). A obrigatoriedade era a regra no Direito Sancionador, com raras exceções que deveriam estar expressamente previstas em lei (Alves, 2017, p. 914-916).

Nada obstante, mesmo naquela época, grande parte da doutrina, da jurisprudência e do próprio Conselho Nacional do Ministério Público - CNMP, por meio da Resolução nº 179/2017, já contemplava a hipótese de consensualidade no âmbito da Lei de Improbidade Administrativa, tanto na esfera extrajudicial como judicial.

Ocorre que nesses aproximadamente 28 anos de vigência da LIA, o ordenamento jurídico passou gradativamente a abandonar o dogma da impossibilidade jurídica de transação em demandas envolvendo a Administração Pública.

O emprego de instrumentos consensuais em matéria de direito sancionador prenunciava-se como consequência inarredável da evolução do Direito Administrativo e da Constituição Federal, cujo Art. $1^{\circ}$ adotou o Estado Democrático de Direito, contemplando, implicitamente, o princípio da consensualidade.

O princípio da indisponibilidade do interesse público não constitui óbice à consensualidade administrativa, na medida em que o acordo representa mero instrumento para alcançar o interesse público no caso concreto, com benefícios de maior eficiência e legitimidade da ação administrativa. Ao adotar métodos consensuais, o administrador não dispõe do interesse público, mas o persegue por outro meio que não o ato administrativo unilateral e imperativo (Lopes, 2017, p. 383-407).

Os instrumentos consensuais apresentam menor custo e são mais aceitáveis, se comparados com a judicialização de ações de improbidade administrativa, cujo trâmite não raro perdura por anos. ${ }^{6}$ Há uma convergência, portanto, com o princípio da eficiência da Administração Pública, que foi introduzido na Constituição Federal pela Emenda Constitucional no $19 / 98$.

A obsoleta visão da impossibilidade de consenso em conflitos envolvendo a Administração Pública começa a ser superada a partir do início da implementação de técnicas de justiça penal consensual inauguradas pela Lei 9.099/95, que passou a admitir em determinadas infrações penais, a composição civil, a transação penal e a suspensão condicional do processo. E adquire vigor a partir da promulgação das Leis $\mathrm{n}^{\mathrm{o}} \mathrm{S} 12.529 / 2011$ e 12.846/2013, que tratam, respectivamente, do acordo de leniência em relação às infrações à ordem econômica e em atos contra a Administração Pública. Some-se a possibilidade de conciliação (Art. 10, parágrafo único da Lei no 10.259/01 e Art. 174 do CPC) e mediação (Art. $3^{\circ}$ da Lei ${ }^{\circ}$ 13.140/15) em causas do Estado, a ausência de ajuizamento de execução fiscal de pequeno valor (Art. 20 da Lei 10.522/02 e

\footnotetext{
${ }^{6}$ Em 2015, intentando realizar diagnóstico acerca dos processos de Improbidade Administrativa, mormente quanto à sua tramitação, o Conselho Nacional de Justiça (CNJ) realizou pesquisa, na qual colheu dados de 132 processos, dos Tribunais de Justiça do Estado de São Paulo, Mato Grosso, Rio Grande do Norte, Pará, Tribunal Regional Federal da $4^{a}$ Região e Superior Tribunal de Justiça, onde se expôs que, nesse último, a média de tramitação (dentre a data do ajuizamento e do trânsito em julgado) é de 2.666,40 dias, ou seja, aproximadamente 7 (sete) anos. O resultado da média realizada entre todos os tribunais mencionados foi de 1.855,83 dias (aproximadamente 5 anos) (Brasil, Conselho Nacional de Justiça. Lei de improbidade administrativa: obstáculos à plena efetividade do combate aos atos de improbidade. $1^{\mathrm{a}}$ Edição Série Justiça Pesquisa. Coordenação Luiz Manoel Gomes Júnior, equipe Gregório Assagra de Almeida; et al. Brasília: Conselho Nacional de Justiça, 2015. 〈https://www.cnj.jus.br/wp-content/uploads/2011/02/1ef013e1f4a64696eeb89f0fbf3c1597.pdf>
} 
Arts. $7^{\circ}$ e $8^{\circ}$, ambos da Lei $\left.n^{\circ} 12.514 / 11\right)$ e a realização de acordos ou transações em juízo pela Advocacia-Geral da União e pelos dirigentes máximos das empresas federais (Art. $2^{\circ}$ da Lei n ${ }^{\circ}$ 9.469/97).

Merece lembrança a Lei nº 13.655/18, que inseriu o Art. 26 na Lei de Introdução às Normas do Direito Brasileiro (Decreto-Lei n ${ }^{\circ}$ 4.657/42) para admitir a celebração de termo de compromisso para "eliminar irregularidade, incerteza jurídica ou situação contenciosa na aplicação do direito público, inclusive no caso de expedição de licença" e a possibilidade do "emprego de mecanismos privados para resolução de disputas decorrentes ou relacionadas ao contrato [de concessão], inclusive a arbitragem" (Art. 23-A da Lei n. 8.897/1995).

Na mesma linha, a Lei 13.105/15 (Código de Processo Civil), aplicável subsidiariamente ao procedimento especial da ação de improbidade administrativa por força do seu Art. 318, parágrafo único, ao estabelecer que "a conciliação, a mediação e outros métodos de solução consensual de conflitos deverão ser estimulados por juízes, advogados, defensores públicos e membros do Ministério Público, inclusive no curso do processo judicial” (Art. $3^{\circ}, \S^{\circ}$ ).

Por último, destaca-se a recente e polêmica Lei no 13.964/19, rotulada de Pacote Anticrime, que alterou os sistemas penal e processual penal para incluir, dentre outras, a figura do juiz de garantia e o acordo de não persecução penal para determinados crimes (Art. 28-A do Código de Processo Penal).

Todo este arcabouço normativo integra o chamado microssistema anticorrupção, composto por normas infraconstitucionais cujos enunciados interagem entre si, por meio de um diálogo entre as fontes, de molde a permitir a construção de uma solução lógica e coerente. Conforme esclarece Cláudia Lima Marques ao tratar do direito do consumidor,

Erik Jayme em seu Curso Geral de Haia de 1995, ensinava que, em face do atual "pluralismo pós-moderno" de um direito com fontes legislativas plúrimas, ressurge a necessidade de coordenação entre as leis no mesmo ordenamento (...). O uso da expressão "diálogo das fontes", é uma tentativa de expressar a necessidade de uma aplicação coerente das leis de direito privado, coexistentes no sistema. É a denominada "coerência derivada ou restaurada" (cohérence dérivée ou restaurée), que, em um momento posterior à descodificação, à tópica e à microrrecodificação, procura uma eficiência não só hierárquica, mas funcional do sistema plural e complexo de nosso direito contemporâneo, a evitar a "antinomia", a "incompatibilidade" ou a "não coerência" (Marques, Benjamin \& Bessa, 2009, p. 90).

A teoria do diálogo das fontes, embora adaptada para o direito do consumidor, se aplica a qualquer ramo do direito, por estar inserida nas preocupações com a hermenêutica jurídica. A interpretação sistemática do ordenamento jurídico exige a aplicação simultânea, coerente e coordenada de diversas fontes legislativas, integrando leis gerais (como o Código de Processo Civil) com leis especiais (como a Lei da Ação Civil Pública, a Lei de Improbidade Administrativa e a Lei das Eleições), para que se extraia a maior eficiência possível do sistema jurídico (Cambi \& Sobreiro Neto, 2020).

Com isso, evita-se o "tudo ou nada" na aplicação das regras jurídicas contrapostas. Segundo Ronald Dworkin (2002, p. 39), as "regras são aplicáveis à maneira tudo ou nada. Dados os fatos que uma regra estipula, então ou a regra é válida, e neste caso a resposta que ela fornece deve ser aceita, ou não é válida, e neste caso em nada contribui para a decisão". A teoria do diálogo das fontes, ao invés de resolver as antinomias jurídicas pelos critérios tradicionais da hierarquia, da especialidade e cronológico, opta pela interpretação sistemática e coordenada.

Diante do cenário normativo até então vigente, em que se admite a solução negociada para causas penais (ultima ratio do Direito Sancionador), seria no mínimo incoerente admitir a composição via colaboração premiada, Lei Anticorrupção ( ${ }^{\circ}$ 12.846/2013) e, mais recentemente, o plea bargain (ainda que à brasileira) sem que a improbidade administrativa admitisse tal instrumento jurídico. Além de violar diretamente o microssistema do processo coletivo, geraria incoerência na unidade da Constituição e retiraria do cidadão e dos órgãos públicos relevante instrumento de eficiência na recomposição do patrimônio lesado, imposição de sanções e prevenção de novos atos de improbidade. Haveria aí uma verdadeira contradição axiológica, um defeito de lógica legislativa no plano deontológico (Garcia, 2017, p. 542-595). 
Há que se realçar que o movimento pela consensualidade no Direito Sancionador não é uma exclusividade do ordenamento jurídico brasileiro. Em países de tradição jurídica do common law, como os Estados Unidos, onde impera o sistema adversarial, vige o chamado plea bargain (ou barganha da pena); na Itália, o pateggiamento sulla pena; na Espanha, o la conformidade; e na Alemanha, o absprachen (Cambi, Lima \& Novak, 2020, p. 170-189). ${ }^{7}$

Nos Estados Unidos, por exemplo, desde a década de 1980, foram aprovados pelo menos cinco diplomas que passaram a incentivar a resolução de conflitos e atualmente cerca de $90 \%$ (noventa por cento) de todos os procedimentos criminais encontram resolução por meio do plea bargain (Santos \& Marques, 2020, p. 291-314). Na União Europeia, segundo Christiano Jorge Santos e Silvio Antonio Marques (2020, p. 291-314),

a Diretiva 2008/52/CE, de 21.05.2001, foi editada com o objetivo de facilitar a solução amigável de litígios, incentivando o recurso à mediação, enquanto a Diretiva 2013/11/UE, de 21.05.2013, foi aprovada para proporcionar a solução extrajudicial simples, rápida e pouco onerosa de litígios entre consumidores e comerciantes.

No mesmo sentido, compromissos internacionais assumidos pelo Brasil que autorizam a autoridade administrativa a celebrar acordos com infratores, a exemplo da Convenção das Nações Unidas contra a Corrupção - CNUCC -, ratificada pelo Decreto Legislativo n 348/2005 e promulgada pelo Decreto Presidencial n 5.687/2006, conhecida por Convenção de Mérida, e da Convenção das Nações Unidas contra o Crime Organizado Transnacional, conhecida por Convenção de Palermo, promulgada pelo Decreto ${ }^{\circ} 5.015$ de 12 de março de 2004.

Do exposto, colhe-se que a recente alteração do Art. $17, \S^{\circ}$ da Lei n. ${ }^{\circ} 8.429 / 1992$ nada mais é que a concretização de uma tendência já implantada tanto no plano nacional como internacional, no sentido de prestigiar o método autocompositivo na solução dos conflitos em detrimento do heterocompositivo, no qual a decisão é entregue a terceira pessoa, em caráter imperativo (Dias \& Pereira, 2020, p. 361-383).

No entanto, o mérito do legislador ao permitir a solução consensual aos casos de improbidade administrativa poderia ter sido ainda maior, não fosse o veto presidencial ao dispositivo que disciplinava os parâmetros procedimentais e materiais para celebração do acordo (Art. 17-A da Lei no 8.429/1992).

Há uma verdadeira lacuna no ordenamento jurídico quanto regime jurídico e ao modo de operacionalização do acordo de não persecução cível (elementos, condições, limites, etc), debate que precisa ser enfrentado no âmbito acadêmico e com o qual este breve ensaio pretende contribuir.

\section{Aspectos Gerais do Acordo de Não Persecução Cível}

O ANPC pode ser compreendido como a possibilidade do legitimado à proposição da ação civil pública pela prática de ato de improbidade administrativa realizar um negócio jurídico com o autor do fato ímprobo, na fase da investigação ou após judicialização da pretensão (antes ou após o recebimento da petição inicial), destinado a imposição de uma ou algumas sanções previstas no Art. 12 da Lei de Improbidade Administrativa. Em contrapartida, o autor do fato ímprobo não se submete ao processo, evitando todos os ônus dele advindos, dentre os quais honorários de advogado, medidas assecuratórias patrimoniais, procrastinação do processo em decorrência da morosidade da justiça (Castro, 2020, p. 209-235).

Sob a ótica da teoria do fato jurídico, a natureza jurídica do ANPC é de negócio jurídico bilateral e comutativo, cujo aperfeiçoamento opera-se com a manifestação de vontade das partes e com a fixação de prestações certas e determinadas. Renato de Lima Castro (2020, p. 209-235) considera o ANPC como um negócio sui generis, em decorrência da reduzida liberdade das partes intervenientes na convenção para negociar, já que as sanções devem ser proporcionais à maior ou menor

\footnotetext{
${ }^{7}$ Ver também: Cabral, Antônio do Prado. Convenções processuais. (2a ed.), Juspodivm, 2018, p. 254.
} 
gravidade do injusto ímprobo, não admitindo absoluta liberalidade na negociação (Castro, 2020, p. 209-235).

O infrator, portanto, não estará irrestritamente apto a negociar todo o negócio jurídico, mas apenas parte dele. Não é diferente em relação ao proponente do acordo que não está livre para estabelecer as condições que bem lhe aprouver. Tanto o Ministério Público, como a pessoa jurídica interessada, devem subserviência aos princípios e normas que regem as respectivas atuações na defesa da probidade administrativa e do patrimônio público, sem olvidar, no tocante às sanções, da proporcionalidade em relação à gravidade do fato ímprobo.

O acordo pode assumir feição de negócio jurídico processual nas situações em que há fixação de situações jurídicas processuais, por exemplo, o autor do fato ímprobo, renunciando ao direito ao silêncio, assume o compromisso de confessar e identificar os demais envolvidos na infração, concorda com a redução de prazos legais ou renuncia desde logo aos prazos recursais, dentre outras situações.

Acerca da legitimidade para celebração do acordo, parece não remanescer maiores dúvidas: os mesmos que a detém para propositura da ação de improbidade administrativa, ou seja, Ministério Público e a pessoa jurídica interessada (Art. 17 da Lei $\left.{ }^{\circ} 8.429 / 1992\right)$.

A convenção pode se dar tanto no âmbito extrajudicial quanto no judicial. Naquela hipótese, evita-se o ajuizamento da ação civil pública de improbidade administrativa. Nessa, o acordo determina a resolução do processo com julgamento de mérito, nos moldes do Art. 487, inc. III, alínea "b", CPC/2015. De toda sorte, em ambas as situações, homologado judicialmente, o instrumento adquire eficácia de título executivo judicial (Art. 515, inc. II, do CPC/2015).

Em razão da independência de instâncias, a celebração do acordo não afasta responsabilização administrativa e penal pelo mesmo fato (Art. $1^{\circ}, \S 3^{\circ}$ da Resolução $\mathrm{n}^{\circ}$ 179/17 do CNMP), tampouco importa reconhecimento automático de responsabilidade para fins diversos dos expressamente estabelecidos no acordo.

Nada impede que exista um diálogo entre as esferas penal, administrativa e cível, de modo a autorizar que a convenção se estenda para além dos limites da improbidade administrativa. ${ }^{8}$ Nessa hipótese, será necessária uma reunião entre todos colegitimados na negociação, no sentido de participar do acordo de não persecução cível e firmar conjuntamente o instrumento, vinculando-os aos termos da convenção.

Releva consignar que o interessado não goza de direito subjetivo à realização do acordo, assim como dele não dispõe o réu da ação penal no tocante ao benefício da suspensão condicional do processo, consoante orientação pacífica dos Tribunais Superiores. A proposta deve contar com a anuência dos legitimados ativos e não pode ser objeto de imposição, seja pelos legitimados ativos, seja pelo investigado ou pelo Poder Judiciário, conforme já defendido por um dos autores em outra oportunidade (Gajardoni, et al., 2020, p. 371-372). ${ }^{9}$

Enfrentados os pontos em relação aos quais não remanescem maiores divergências, passa-se a abordar algumas questões controvertidas acerca do ANPC.

\section{Aspectos Controversos do Acordo de não Persecução Cível}

O Pacote Anticrime - Lei nº 13.964/19, em que pese representar inovação ao tratar da implementação de acordo de não persecução cível acarretou alguns aspectos controversos como serão abordados.

\footnotetext{
${ }^{8}$ A atuação coordenada entre órgãos de um mesmo Ministério Público já havia sido externada em caso da Operação Lava Jato, pela $5^{\text {a }}$ Câmara de Coordenação e Revisão do Ministério Público Federal (Brasília, $5^{\mathrm{a}}$ Câmara de Coordenação e Revisão do Ministério Público Federal. Voto 9212/2016, inquérito civil 1.30.001.001111/2014-42, rel. Procuradora Mônica Nicida Garcia. http://www.mpf.mp.br/pgr/documentos/IC1.30.001.001111.201442_Reduzido.pdf.)

${ }^{9}$ Cfr. Gajardoni, et al., Comentários à Lei de Improbidade Administrativa. (4a ed.), RT, 2020.
} 


\subsection{Limite temporal para celebração do acordo}

Um primeiro pensamento a respeito da temática propõe que o termo final para celebração do ajuste seja o oferecimento da contestação, pois, segundo o Art. 17, §10-A, da LIA, "Havendo a possibilidade de solução consensual, poderão as partes requerer ao juiz a interrupção do prazo para a contestação, por prazo não superior a 90 (noventa) dias." (Castro, 2020, p. 209-235).

Para os adeptos dessa forma de pensar, a interpretação vai ao encontro das razões do veto ${ }^{10}$ ao $\S 2^{\circ}$ do Art. 17 e atende o princípio da celeridade processual, uma vez que não seria razoável permitir a alguém que aguardou todo trâmite processual ou mesmo o postergou voluntariamente, apostando em alguma eventualidade (“v.g.", prescrição), pudesse vir a ser contemplado ao final da demanda com o benefício legal. Não é essa a orientação de Armando Antonio Sobreiro Neto e Eduardo Cambi: "pouco sentido faria relativizar a aplicação das regras materiais de Direito Público mantendo a mesma rigidez e formalismo no direito processual clássico. A justiça negociada exige novos paradigmas para produzir resultados mais eficientes." (Cambi \& Sobreiro Neto, 2020).

Em sentido oposto, há quem considere adequado o trânsito em julgado da sentença condenatória como limite temporal para celebração do acordo de não persecução cível. Argumenta-se que a lei não estabeleceu um termo final e que o $\$ 2^{\circ}$ do artigo 17 da LIA, em verdade, trata apenas da possibilidade de suspensão do prazo da contestação, caso as partes sinalizem a possibilidade de acordo, e não retira essa faculdade se, posteriormente, pretendam elas retomar a solução negocial frustrada (Andrade, Masson \& Andrade, 2020, p. 995).

E há aqueles que, sem desconsiderar o limite da coisa julgada, admitem o acordo de não persecução cível após o trânsito em julgado (Gajardoni, et al., 2020, p. 367-368). Sustenta-se que, além de inexistir vedação legal, em algumas situações, a fixação de um termo final poderia contrariar a própria finalidade da Lei no 8.429/1992, ao subtrair das partes uma das mais relevantes finalidades do processo: a pacificação da problemática social subjacente à causa. É a hipótese, "v.g.”, de cumprimento de sentença de improbidade administrativa em que o exequente não localiza bens em nome do devedor. Se em algum momento este se dispor a pagar a dívida mediante a celebração de acordo, não haverá razão, lógica e jurídica, para impedi-lo a fazer.

Nas exatas palavras dos subscritores:

O objetivo deve ser o melhor resultado para a defesa do interesse público e o acordo pode resultar em um desfecho melhor que o título executivo judicial. A análise deve ser feita caso a caso, nada havendo no sistema que vede a possibilidade, ainda que após o término do processo, como aliás em qualquer demanda judicial (GAJARDONI, et al., 2020, p. 368).

A posição parece coerente e razoável do ponto de vista pragmático e dogmático, pois, não se pode perder de mira quando da celebração do acordo de não persecução cível, a defesa do interesse e do patrimônio público, que restaria prejudicada, em determinados casos, se mantida a inflexível fixação de limite temporal.

O relevante deve ser sempre a defesa de um resultado que melhor assegure a preservação do interesse público.

\subsection{Necessidade de homologação do acordo de não persecução cível e de participação do colegitimado}

Uma vez proposto o acordo de não persecução cível, interessa saber se caberia, ou não, ao Conselho Superior dos Ministérios Públicos Estaduais, às Câmaras de Revisão do Ministério Público da União e ao órgão superior da pessoa jurídica lesada, homologar o instrumento e se a homologação judicial seria, ou não, obrigatória.

Na fase extrajudicial, parece não remanescer dúvidas quanto a necessidade de homologação tão somente pelo órgão

10 <http://www.planalto.gov.br/ccivil_03/_Ato2019-2022/2019/Msg/VEP/VEP-726.htm> 
superior do Ministério Público ou do órgão ou entidade da Administração Pública lesada. ${ }^{11}$ Armando Antonio Sobreiro Neto e Eduardo Cambi citam interessante hipótese de acordo de não persecução cível em improbidade administrativa eleitoral que prescinde de homologação judicial, consistente na obrigação para retirar propagandas de sites, etc (Cambi \& Sobreiro Neto, 2020). Nesse caso, não haveria nenhum conflito de interesse passível de exame judicial, tampouco prejuízo à liberdade de expressão.

Excepcionam-se as hipóteses de suspensão dos direitos políticos, perda da função pública e proibição de contratar com o Poder Público. Apesar de inexistir regra expressa nesse sentido e conquanto o acordo tenha força de título executivo extrajudicial (Art. $5^{\circ}, \S 6^{\circ}$, da Lei 7.347/85), é imprescindível o controle do próprio órgão superior ministerial ou da pessoa jurídica lesada, seguido da homologação judicial. Reclama-se o duplo controle porque se está diante de sanções das mais severas previstas na Lei $n^{\circ} 8.429 / 1992$, cujos efeitos atingem direitos fundamentais de alta densidade (direitos políticos, liberdade de trabalhar, livre iniciativa, etc).

Nem se cogite que o Art. 20, caput, da Lei n ${ }^{\circ}$ 8.429/92 (“A perda da função pública e a suspensão dos direitos políticos só se efetivam com o trânsito em julgado da sentença condenatória") justificaria a retirada da sanção de perda da função pública do âmbito de negociação do acordo de não persecução cível, pois tal dispositivo visa limitar tão somente a concessão de tutelas jurisdicionais provisórias, e não propriamente impedir a justiça negociada.

Não faria sentido tornar inválida uma sanção aceita de forma livre e voluntária pelo autor do ato ímprobo, se semelhante lógica se aplica a outras composições do gênero, a exemplo dos acordos de não persecução penal (Art. 28-A do CPP) e de colaboração processual (Art. $4^{\circ}$ da Lei $n^{\circ} 12.850 / 13$ ).

Não se justifica do ponto de vista lógico, a distinção entre um investigado que confessa a prática delitiva e se sujeita, espontaneamente, às restrições penais, sem condenação judicial, daquele agente ímprobo, que reconhece a prática da improbidade administrativa e aceita celebrar acordo de não persecução cível.

Ainda que se possa argumentar que não se trata da imposição de sanções, mas de obrigações equivalentes às sanções (Pereira, 2020, p. 211-235), não se pode afirmar que um acordo de vontades fere a cláusula do devido processo legal (Art. 5º, inc. LV, CF). Não há coação, mas livre negociação em torno dos termos do acordo, que poderá, ou não, ser acatado pelo compromissário e seu advogado. O controle posterior submete a um terceiro alheio ao negócio jurídico a análise acerca da legalidade, da adequação, suficiência e legalidade das cláusulas da convenção, reforçando a constitucionalidade do instituto.

Nunca é demasiado lembrar que nenhum direito fundamental é absoluto. Essa perspectiva, se aplicada ao acordo de não persecução cível, traduz a ideia de um ajuste em que se relativizam determinados direitos fundamentais à vista de outros que, à luz da solução do caso concreto, encerram maior densidade e, como tal, merecem preponderância (Dworkin, 2002, p. 39).

Segundo parcela da doutrina, (Andrade, Masson \& Andrade, 2020, p. 995) quando o acordo é celebrado na fase judicial e não envolve nenhuma daquelas três sanções, prescinde da análise pelo órgão interno do Ministério Público, em razão do texto expresso no Art. $6^{\circ}, \S^{\circ}$, da Resolução no $179 / 2017$ do CNMP. ${ }^{12}$ Semelhante solução se aplica ao acordo celebrado por órgão ou entidade da Administração Pública lesada pelo ato de improbidade administrativa. Bastaria, pois, a mera homologação judicial. Há, no entanto, quem reclame a participação do órgão colegiado superior (Pereira, 2020, p.211-235). Argumenta-se que o controle evitaria que um terceiro estranho analisasse o mérito do acordo, fugindo da ideia de

\footnotetext{
${ }^{11}$ Cfr. Art. $5^{\circ}, \S \S 4^{\circ}-6^{\circ}$, da Resolução 01/2017 do MPPR, e Art. 10 da Resolução n ${ }^{\circ} 1.193 / 2020$ do MPSP.

12 "Art. $6^{\circ}$ Atentando às peculiaridades do respectivo ramo do Ministério Público, cada Conselho Superior disciplinará os mecanismos de fiscalização do cumprimento do compromisso de ajustamento de conduta tomado pelos órgãos de execução e a revisão pelo Órgão Superior do arquivamento do inquérito civil ou do procedimento no qual foi tomado o compromisso, observadas as regras gerais desta resolução. $§ 1^{\circ}$ Os mecanismos de fiscalização referidos no caput não se aplicam ao compromisso de ajustamento de conduta levado à homologação do Poder Judiciário".
} 
autocomposição. Invoca-se ainda a noção de uniformização dos acordos substitutivos, com base no fundamento de que, enquanto o juiz analisa o acordo de não persecução cível de determinado caso concreto, o órgão superior (seja do Ministério Público, seja do ente público lesado) o faz em relação a todos ajustes que estão sob sua órbita de atuação.

De qualquer forma, é recomendável que o agente do Ministério Público ou do ente público lesado, antes da homologação do acordo (Art. 17, $\S 1^{\circ}$, da Lei no $8.429 / 92$ ), intime a pessoa jurídica de direito público lesada para dele tomar ciência e, querendo, intervir, por se tratar de colegitimada na celebração de compromisso de ajustamento de conduta (Art. $5^{\circ}$, $\S 6^{\circ}$, da Lei $n^{\circ} 7.347 / 85$ ) e na propositura da ação civil pública por improbidade administrativa (Art. 17, caput, da Lei $n^{\circ}$ 8.429/92).

Embora se trate de legitimidade concorrente e disjuntiva, de molde a prescindir da anuência, autorização e/ou participação do colegitimado, dúvidas não há de que a manifestação da advocacia pública ou do respectivo órgão de representação jurídica do ente lesado inibe a celebração de acordos incompletos e que possam vir a ser questionados perante o Poder Judiciário. Com isso, confere-se maior segurança jurídica ao cumprimento do ajuste.

Em caso de dissenso entre colegitimados, seja total ou parcial (v.g., irresignação quanto a determinada cláusula pactuada), o acordo permanecerá válido e eficaz. No entanto, nada impede que o resiliente o questione judicialmente. Conforme lecionam Luiz Manoel Gomes Junior et al. (Gajardoni, et al., 2020, p. 372). "Não se pode admitir que caprichos ou simples posições pessoais possam impedir a realização dos acordos." Se algum(ns) do(s) legitimado(s) se sentir(em) lesado(s) juridicamente pelo acordo levado a efeito pelo colegitimado, sempre haverá a possibilidade da via recursal para veicular a insurgência, "mas não resta viável a utilização de uma oposição, de uma barreira intransponível, por si só, à realização de acordos." (Gajardoni, et al., 2020, p. 372).

Por outro lado, quando o ANPC vier a ser celebrado pelo ente público lesado, também se faz necessária a intervenção do Ministério Público. Se a atuação do Ministério Público é obrigatória como fiscal da ordem jurídica, na ação civil pública por improbidade administrativa ajuizada pela pessoa de direito público lesada (Art. 17, §4 ${ }^{\circ}$, da Lei 8.429/92), com maior razão a atuação fiscalizadora deve ocorrer nos acordos de não persecução cível discutidos pela pessoa de direito público lesada, mormente quando necessitam de homologação judicial, o que se propõe com base no Art. 127, "caput", Constituição Federal.

Além disso, nunca é demasiado rememorar que a instituição tem legitimidade para executar o compromisso de ajustamento de conduta firmado por outro ente público, em caso de omissão no descumprimento das obrigações assumidas (Art. 12 da Resolução 179/2017 do CNMP), de modo que a sua intervenção é imperiosa.

\subsection{Acordo de não persecução cível em casos de solidariedade passiva}

Não menos relevante é a celebração de acordo de não persecução cível em casos de solidariedade passiva. Por um lado, o Art. 264 do Código Civil dispõe que: "Há solidariedade, quando na mesma obrigação concorre mais de um credor, ou mais de um devedor, cada um com direito, ou obrigado, à dívida toda." Por outro, o Art. 844 do mesmo Código estabelece: "A transação não aproveita, nem prejudica senão aos que nela intervierem, ainda que diga respeito a coisa indivisível."

Em casos de solidariedade passiva em matéria de improbidade administrativa, se a obrigação for de caráter divisível, parece não remanescer maiores controvérsias quanto a possibilidade de estabelecer à cota parte da dívida para fins de acordo. Diferente é a hipótese de obrigação indivisível, em que a autocomposição parcial restará prejudicada se não contar com a intervenção e concordância de todos os devedores.

A propósito, o Superior Tribunal de Justiça (STJ) entende que não há litisconsórcio passivo necessário na ação de improbidade administrativa entre agentes públicos e eventuais terceiros beneficiários ou participantes. ${ }^{13}$

13 Superior Tribunal de Justiça. AREsp 1579273/SP, Rel. Ministro Francisco Falcão, Segunda Turma, julgado em 10/03/2020, DJe $17 / 03 / 2020$ 
Pelo Art. $3^{\circ}$ da Lei no 8.429/92, as "disposições desta lei são aplicáveis, no que couber, àquele que, mesmo não sendo agente público, induza ou concorra para a prática do ato de improbidade ou dele se beneficie sob qualquer forma direta ou indireta". É certo que as sanções da Lei de Improbidade também alcançam os particulares que, de qualquer forma, tenham concorrido para o ato ímprobo. ${ }^{14} \mathrm{O}$ que não se admite é o ajuizamento da ação de improbidade administrativa exclusivamente em face de particulares, sem a concomitante presença de agente público no polo passivo da demanda. ${ }^{15}$ Por essa ótica, seria inadmissível a celebração de acordos parciais de não persecução cível em que figura como compromissário apenas o particular enredado na improbidade.

Esse posicionamento, de certa forma, é contraditório com a própria jurisprudência do STJ, na medida em que, como visto, a Corte reconhece a inexistência de litisconsórcio passivo necessário. Ressalvada a já mencionada situação de indivisibilidade, seria desarrazoado exigir que todos investigados concordem com a autocomposição para que o Ministério Público ou qualquer um dos colegitimados aproveitem a colaboração do agente público investigado na celebração do acordo de não persecução. Se inviável a discussão conjunta, não haveria dificuldade alguma para as condutas serem analisadas e processadas em processos distintos. Nesse sentido, obtempera Sofia Cavalcanti Campelo:

Como a escolha por demandar mais de um devedor solidário é um direito do credor, parece possível - e razoável que o MP e/ou a pessoa jurídica lesada renuncie, em relação ao signatário do acordo, ao direito de cobrar a totalidade do valor arbitrado a título de reparação de danos, apenas exigindo a sua parte da obrigação, quer no acordo, quer em futura ação judicial (2020, p. 102).

Como medida alternativa, poderão os colegitimados, ao optarem pelo ajuizamento da ação de improbidade administrativa, perseguir apenas o efeito declaratório (reconhecimento da improbidade), no tocante ao agente público que participou do ANPC, ao argumento de com ele já ter ajustado as sanções cabíveis e, em relação ao particular, requerer provimento de natureza condenatória, se este não tiver interesse ou não for incluído no acordo.

\subsection{A previsão de cláusulas pró-futuro nos acordos de não persecução cível}

Além das consequências indesviáveis - reparação do dano e perda dos bens acrescidos ilicitamente - o acordo de não persecução cível poderá prever sanções de natureza cível, administrativo-funcionais e políticas (Cambi; Bortoncello \& Lima, 2021, p. 187-201).

A composição sobre as reprimendas criminais exigirá procedimento próprio de acordo com a recente Lei no 13.964/19 (Pacote Anticrime). Dúvida não há sobre o cabimento das sanções de efeito imediato. A questão é: seria possível o acordo prever cláusulas pró-futuro, ou seja, de efeito automático em caso de reiteração do ato ímprobo?

Como exposto, embora de severa consequência, é inegável que toda e qualquer sanção nas searas cível, administrativo-funcionais e políticas pertencem ao rol de disposição do agente. Desde a perda dos bens ou valores acrescidos ilicitamente ao patrimônio até a perda da função pública, suspensão de direitos políticos e proibição de contratar com o poder público, não há nenhuma impossibilidade na composição. Não se ignora a dificuldade em acreditar que o investigado por ato ímprobo aceite acordo que estabeleça todas as sanções previstas na LIA, cumulativamente. Difícil, mas não impossível.

Convém observar que a fixação de sanções condicionais - pró-futuro - além de representar maior preservação da probidade administrativa, empresta ao acordo maior probabilidade de concretização e completa execução. Quando o autor da improbidade, por exemplo, em ato ímprobo de menor vulto, além de ressarcir integralmente o erário, de pagar multa civil e de perder os bens acrescidos ilicitamente, se comprometer a perder a função pública, a ter seus direitos políticos suspensos ou

${ }^{14}$ Superior Tribunal de Justiça. REsp 1.789.492/PR, Rel. Ministro Francisco Falcão, Segunda Turma, Dje 23/5/2019.

15 Superior Tribunal de Justiça. REsp 1678206/RS, Rel. Ministra Assusete Magalhães, Segunda Turma, julgado em 26/05/2020, DJe $05 / 06 / 2020$. 
reste proibido de contratar com o poder público por "x" anos, obviamente haverá redobrada atenção não só no cumprimento do acordo, mas, especialmente, nos atos comissivos e omissivos à frente da coisa pública.

Não se pode olvidar que as cláusulas pró-futuro contendo novas sanções, resguardam, inclusive, a dupla afetação do patrimônio público, pois a reiteração da improbidade acaba por merecer maior e severa reprimenda em razão do desprezo, pelo gestor e eventual coinvestigado, da probidade e legalidade necessárias.

\subsection{Acordo de não persecução cível e independência de instâncias}

De complexa abordagem - e apenas a detalhada análise do caso concreto permitirá fazê-la com a qualidade necessária - é a repercussão da absolvição criminal, pelos mesmos fatos que ensejaram a improbidade administrativa, após a celebração do acordo de não persecução cível (Cambi; Bortoncello \& Lima, 2021, p. 187-201).

Sem dúvidas, não é toda e qualquer absolvição criminal que vai gerar efeito na seara cível, sendo a autonomia das esferas assunto já pacificado.

Contudo, nas hipóteses em que o juiz declara a inexistência do fato ou a exclusão da autoria, o autor poderia buscar, judicialmente ou por composição com o Ministério Público, a anulação do acordo e o retorno ao status quo ante?

Em regra, a resposta é negativa em razão da voluntariedade do acordo que versa sobre direitos disponíveis.

Sem embargo, há situações em que o caso concreto admitirá a anulação do acordo. Ocorre, por exemplo, quando a ação penal trouxer um rol probatório mais extenso e qualificado, com provas desconhecidas e/ou que não puderam ser produzidas ao longo do inquérito civil ou da ação civil pública.

No entanto, quando não houver consistente inovação no quadro probatório com provas impossíveis de serem produzidas ou desconhecidas pela parte interessada, o rigor sobre a segurança jurídica do acordo deve ser observado.

\subsection{Os limites do controle judicial sobre o acordo de não persecução cível}

Dentre as estruturas clássicas de resolução de conflitos e técnicas alternativas de solução de disputas sociais, encontram-se a autotutela, a autocomposição e a heterocomposição.

A autotutela é considerada o meio mais primitivo de solução de conflitos. Por intermédio dela, resolvia-se a querela com as próprias mãos. Conforme Maurício Godinho Delgado, "a autotutela ocorre quando o próprio sujeito busca afirmar, unilateralmente, seu interesse, impondo-o (e impondo-se) à parte contestante e à própria comunidade que o cerca." (Delgado, 2002, p. 663). Exemplo clássico é o direito de greve, previsto no Art. $9^{\circ}$ da Constituição Federal e regulamentado pela Lei ${ }^{\circ}$ 7.783/1989.

$\mathrm{Na}$ autocomposição, por sua vez, a solução é construída pelas próprias partes envolvidas no litígio, com ou sem a intervenção de terceiros, mas, independentemente disso, sem o uso da força. Nas palavras de Francisco José Cahali, na autocomposição, "embora possa participar um terceiro facilitador da comunicação (inclusive com propostas de solução, conforme o caso), o resultado depende exclusivamente da vontade das partes." (Cambi \& Sobreiro Neto, 2020).

Já na heterocomposição, a decisão sobre o conflito é entregue a uma terceira pessoa, que estabelece, de forma imperativa, a solução do caso concreto. A heterocomposição pode ocorrer de duas formas: a arbitral, quando as partes escolhem um terceiro de sua confiança para decidir a causa; e a jurisdicional, quando uma das partes, valendo-se do direito de ação, provoca o Poder Judiciário, em busca de uma decisão imperativa, dotada de poder coercitivo e em caráter definitivo.

No caso da autocomposição, as partes estão autovinculadas às convenções pelo livre acordo de vontades, enquanto que na heterocomposição, juízes e árbitros estão adstritos ao ordenamento jurídico (heterovinculação), submetendo-se às normas jurídicas - sejam legisladas ou pactuadas (contratos e convenções) (Cambi \& Sobreiro Neto, 2020).

Trazendo essas premissas ao instituto aqui estudado, arremata-se que o acordo de não persecução civil constitui uma 
forma de autocomposição. Por intermédio dele, em troca do não ajuizamento da ação, se extrajudicial, ou da resolução do mérito da demanda, se já ajuizada, as partes negociam aplicação de uma ou de algumas das sanções previstas na Lei de Improbidade Administrativa, conforme a gravidade dos fatos praticados.

No modelo de consensualidade um dos seus pressupostos é a solução negociada pelas próprias partes. Assim, o protagonismo processual, até então centralizado na figura do juiz, desloca-se para os atores envolvidos no conflito (Cabral, 2018, p. 251). Quem, então, define as sanções cabíveis (dentre aquelas, por certo, com previsão constitucional e legal), a forma, o modo com que serão aplicadas e outros aspectos vinculados à operacionalização do acordo são as próprias partes, por meio de uma negociação regrada, a partir de normas constitucionais e infraconstitucionais.

Evidentemente, o Estado-Juiz não ficará alheio ao controle que lhe é pertinente, afinal, como leciona Gajardoni et al. “[...] o Poder Judiciário não é um mero carimbador de acordo" (Gajardoni, et al., 2020, p. 372). Do contrário, sequer haveria necessidade de homologação.

No entanto, o exercício desse controle exige cautela. O juiz, ao analisar o acordo, não pode intervir na proposição do ajuste, tampouco substituir seu conteúdo (Castro, 2020, p. 209-235). Não lhe é dado interferir no mérito do ato jurídico, tampouco no conteúdo de suas cláusulas. O aprofundamento na análise dos requisitos formais e, de maneira excepcional, materiais do acordo de não persecução cível, se não exercido com a prudência necessária, pode eventualmente desvirtuar a natureza do ajuste enquanto negócio jurídico, repercutindo na liberdade e autonomia da vontade das partes, bases do modelo autocompositivo, o que destoa da novel proposta de justiça negociada introduzida no Direito Sancionador brasileiro.

Partindo dessa premissa, se houver discordância do Poder Judiciário em relação à estrita legalidade dos termos do acordo, caber-lhe-á devolvê-lo às partes para adequação pertinente. A dedução é possível por analogia ao acordo de não persecução penal, disciplinado no Art. 28-A do Código de Processo Penal, cujo §5º prescreve:

Se o juiz considerar inadequadas, insuficientes ou abusivas as condições dispostas no acordo de não persecução penal, devolverá os autos ao Ministério Público para que seja reformulada a proposta de acordo, com concordância do investigado e seu defensor.

Esse raciocínio, por certo, não exclui o controle sobre aquelas situações de patente desproporcionalidade e que se enquadraria no exame de legalidade (em sentido lato sensu) já abordado quando do juízo homologatório do acordo.

Porém, mesmo nessas hipóteses, o controle judicial deve se restringir aos casos manifestamente desproporcionais e teratológicos, sob pena de retornar ao vetusto modelo de solução de conflitos em matéria de improbidade administrativa e retroceder no significativo avanço que representou a Lei $\mathrm{n}^{\circ}$ 13.964/2019 (Pacote Anticrime) em termos de celeridade e eficiência no combate à corrupção.

\section{Conclusões}

A nova redação do Art. 17, § $1^{\circ}$ da Lei 8.429/92, para além de acompanhar essa mudança de paradigma do direito sancionador, representou significativo avanço no combate à corrupção.

No entanto, perdeu-se uma grande oportunidade de encerrar definitivamente a discussão sobre diversos temas envolvendo o acordo de não persecução cível em razão da carência de regulamentação sobre aspectos materiais e procedimentais.

A lacuna não impede a efetiva implementação do acordo de não persecução cível, cuja consecução pode se dar mediante uma construção hermenêutica e de interpretação sistemática, por meio do chamado microssistema anticorrupção, com destaque para Lei $n^{\circ}$ 12.529/2011, que trata, dentre outros aspectos, do acordo de leniência em relação às infrações à ordem econômica, e para Lei $n^{\circ} 12.846 / 2013$, que versa sobre a responsabilização administrativa e civil de pessoas jurídicas 
pela prática de atos contra a Administração Pública.

A consensualidade no âmbito da Lei de Improbidade Administrativa foi, de forma inicial, acolhida pela jurisprudência e doutrina pioneira, sendo igualmente recepcionada pelo Conselho Nacional do Ministério Público conforme Resolução $n^{\circ}$ 179/2017.

A constitucionalização do direito nacional com as pautas axiológicas, proteção dos direitos fundamentais e tutela dos direitos coletivos de par com os interesses privados, representou marco teórico relevante em favor da maior eficiência e legitimidade da ação administrativa.

Definir o conceito, a natureza jurídica e a legitimidade são premissas essenciais para delimitar os contornos do acordo de não persecução cível e, assim, compreender as controvérsias que cercam a temática. A partir daí será possível reunir condições mínimas capazes de induzir algumas conclusões, dentre elas a inexistência de termo final para celebração do acordo de não persecução cível, que não encontra limite temporal enquanto se mostrar útil para defesa do interesse e do patrimônio público; nas hipóteses de suspensão dos direitos políticos, de perda da função pública e de proibição de contratar com o Poder Público é imprescindível o duplo controle tanto pelo órgão superior do Ministério Público ou do ente público lesado, quanto do Poder Judiciário; a intervenção no acordo pelo colegitimado que dele não participou, em regra, não constitui requisito de validade e eficácia da convenção, e eventual dissenso imotivado não impede a sua concretização; e que é possível a celebração de acordo em casos de solidariedade passiva envolvendo obrigações divisíveis, inclusive quando o compromissário se restringe ao particular enredado no ato ímprobo.

Ainda, a título de conclusão, identifica-se a possibilidade de previsão de cláusulas pró-futuro nos acordos de improbidade, ou seja, de efeito automático em caso de reiteração do ato ímprobo, na medida em que, além de representar maior preservação da probidade administrativa, empresta ao acordo, maior probabilidade de concretização e completa execução.

A absolvição criminal, após a celebração do acordo de não persecução cível e pelos mesmos fatos que ensejaram a improbidade administrativa, em regra, não afeta os termos do ato jurídico perfeito e acabado, salvo quando a ação penal trouxer um rol probatório mais extenso e qualificado, com provas desconhecidas e/ou que não puderam ser produzidas ao longo do inquérito civil ou da ação civil pública.

O controle judicial sobre os termos do acordo de não persecução cível deve observar a natureza do ajuste enquanto negócio jurídico, cujas bases são a liberdade e autonomia da vontade, próprias do modelo autocompositivo. Eventual intromissão no mérito do acordo significaria retroceder o avanço que representou a Lei no 13.964/2019 - Pacote Anticrime em termos de celeridade e eficiência no combate à corrupção.

\section{Referências}

Alves, R. P. (2017). Improbidade administrativa (9a ed.). Saraiva.

Andrade, A., Masson, C. \& Andrade, L. (2020). Interesses difusos e coletivos (10a ed.). Forense.

Cabral, A. do P. (2018). Convenções processuais (2a ed.). Jus Podivm.

Cahali, F. J. Curso de Arbitragem (5a ed.). Revista dos Tribunais.

Cambi, E. \& Sobreiro Neto, A. A. (2020), Improbidade administrativa eleitoral: notas sobre o acordo de não persecução cível celebrado pelo Ministério Público. Artigo inédito; Tavares, P. T. S. V. \& Netto, E. L. G. de L. Pacote anticrime - as modificações no sistema de justiça criminal brasileiro.

Cambi, E., Lima, D. de A. \& Novak, M. S. (2020), Acordo de Não Persecução Cível. Anais II Encontro Virtual do CONPEDI. Florianópolis: CONPEDI, p. $170-189$.

Cambi, E., Bortoncello, L. G. P. \& Lima, D. de A. L. (2021), A superação da míope interpretação do patrimônio público: o acordo em ato de improbidade administrativa. Revista Eletrônica de Direito Processual, 22(2), 187-201.

Campelo, S. C. (2020), Acordo em Ação de Improbidade Administrativa: Desafios atuais e perspectivas para o futuro. Revista dos Tribunais, vol. 1011.

Castro, R. de L. (2020), Acordo de não persecução cível na Lei de Improbidade Administrativa. Revista do Ministério Público do Estado do Rio de Janeiro, 
Research, Society and Development, v. 10, n. 11, e261011192268, 2021

(CC BY 4.0) | ISSN 2525-3409 | DOI: http://dx.doi.org/10.33448/rsd-v10i11.19268

$77,209-235$.

Conselho Nacional do Ministério Público, Resolução n. ${ }^{\circ}$ 179/2017, de 26 de julho 2017. Disciplina a tomada do compromisso de ajustamento de conduta no âmbito do Ministério Público.

Delgado, M. G. (2002), Arbitragem, mediação e comissão de conciliação prévia no direito do trabalho brasileiro. Revista LTr, 66(6).

Dias, R. G. B. \& Pereira, D. A. F. N. (2020), Justiça multiportas e os conflitos envolvendo a Administração Pública: arbitragem e os interesses públicos disponíveis. Revista Jurídica Unicuritiba, 03(60), 361-383.

Dworkin, R. (2002), Levando os direitos a sério. (3a ed.), Martins Fontes.

Gajardoni, L. F. da, Cruz, L. P. de F., Cerqueira, L. O. S., Gomes Junior, L. M. \& Favreto, R. (2020), Comentários à Lei de Improbidade Administrativa. (4a ed.), RT.

Garcia, E. (2017), A consensualidade no direito sancionador brasileiro: potencial de incidência no âmbito da Lei $\mathrm{n}^{\circ}$ 8.429/1992. Revista Síntese: Direito Administrativo, 12(141).

Lakatos, E. M. \& Marconi, M. de A. (2003), Fundamentos de metodologia científica: Técnicas de pesquisa. (3a ed.), Atlas.

Lopes, P. L. (2017), Atuação administrativa consensual: acordo substitutivo envolvendo atos de improbidade administrativa. Revista de Processo, vol. 274.

Marques, C. L., Benjamin, A. H. \& Bessa, L. R. (2009), Manual de direito do consumidor. (2a ed.), RT.

Mudrovitch, R. de B. \& Nóbrega, G. P. da (2018), Leniência e improbidade: a proposta trazida pelo PL 10.887/2018. Conjur.

Pereira, R. (2020), Parâmetros para aplicação do acordo de não persecução cível criado pelo Pacote Anticrime (Lei nº 13.964/2019). In: Cambi, E.; Silva, D. S., \& Marinela, F. (org.). Pacote anticrime. Curitiba: Escola Superior do Ministério Público do Paraná, 1, 211-235.

Santos, C. J. \& Marques, S. A. (2020), Pacote Anticrime (Lei 13.964/2019) e acordo de não persecução cível na fase pré-processual: entre o dogmatismo e o pragmatismo. Revista de Processo, 303.

Superior Tribunal de Justiça. AREsp 1579273/SP (2020). Relator Ministro Francisco Falcão, Segunda Turma, julgado em 10/03/2020, DJe 17/03/2020.

Superior Tribunal de Justiça. REsp 1.789.492/PR (2019). Relator Ministro Francisco Falcão, Segunda Turma.

Superior Tribunal de Justiça. REsp 1678206/RS (2020). Relatora Ministra Assusete Magalhães, Segunda Turma, julgado em 26/05/2020, DJe 05/06/2020.

Tavares, J. P. L. G. (2018), A aplicação do instituto da colaboração premiada nas ações de improbidade administrativa. Coletânea de artigos: avanços $e$ desafios no combate à corrupção após 25 anos de vigência da Lei de Improbidade Administrativa. $5^{\text {a }}$ Câmara de Coordenação e Revisão, Criminal. Brasília: MPF. 